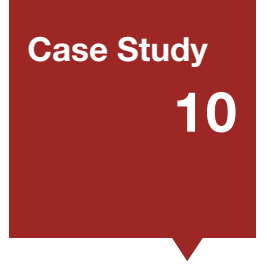

\title{
RDM in the Performing Arts: Living Symphonies by Daniel Jones \& James Bulley (Unit for Sound Practice Research, Goldsmiths, University of London)
}

\author{
Authors: James Bulley (Unit for Sound Practice Research, Goldsmiths, \\ University of London) \& Andrew Gray (Library Services, Goldsmiths, \\ University of London) \\ Email: a.gray@gold.ac.uk
}

\subsection{INTRODUCTION}

Living Symphonies ${ }^{1}$ is a landscape sound installation by James Bulley and Daniel Jones ${ }^{2}$, which toured across four different forests ${ }^{3}$ in the UK in the summer of 2014. The work portrays the thriving activity of the forest's wildlife, plants and atmospheric conditions, creating an ever-changing sound symphony heard from a network of 24 speakers hidden throughout the forest itself. Working with ecologists and wildlife experts across the UK, Jones/Bulley developed highly detailed maps of the flora and fauna that inhabited each forest site where the installation was to take place.

Each species in the surveyed area was depicted by a unique set of musical motifs that portrayed their changing behaviour over day and night, coming to life as the species awakened; moving, developing and interacting just as the organism would. Dozens of these motifs were heard at any moment when the piece was live, spatialised across the space of the forest and heard back through a three-dimensional speaker system. In total there were some 15,000 fragments of sound within the sound score, making up musical movements for over a hundred different organisms.

\subsection{FUNDER REQUIREMENTS}

The piece was commissioned and funded as a collaborative work by Sound and Music, the Arts Council England and the Forestry Commission England. All copyright in the work, including that of the datasets, remained with the artists and there was no requirement to make any such data publicly available. A required outcome was a toolkit for touring public artworks, produced and published by the Forestry Commission England. This toolkit is openly accessible and available here ${ }^{4}$.

\subsection{SURVEY DATA}

In order to undertake the piece, the artists collected a large array of datasets over a year-long period of indepth research and development. This data was used both to create and contextualize the artwork. A table of datasets captured during the project is shown in Figure 10.1. and process-based composition: http://jones-bulley.com/biography/; last accessed 5 March 2017.

The forest sites for the 2014 tour were as follows; Thetford Forest (24-30 May 2014), Fineshade Woods (20-26 June 2014), Cannock Chase (26 July - 1 August 2014), and Bedgebury Pinetum (26 August-7 September 2014).

Sound and Music: http://soundandmusic.org/create/planningandproducingartworksinthenaturalenvironmenttoolkit; last accessed 5 March 2017. 


\begin{tabular}{|c|c|c|c|c|c|c|c|c|c|}
\hline Type of dataset & Format & Size & $\begin{array}{l}\text { Capture } \\
\text { Tools/ } \\
\text { Sofftware }\end{array}$ & Backup/Storage & Raw & Prepared & Shared with & Archived & Accessible \\
\hline $\begin{array}{l}\text { Detailed ecological } \\
\text { surveys of ofur forest } \\
\text { sites captured by } \\
\text { teams of volunteers. }\end{array}$ & $. x \mathrm{~s} /$ /.csv & $\begin{array}{l}20 \\
\text { Mb }\end{array}$ & $\begin{array}{l}\text { Google Docs } \\
\text { / PPad }\end{array}$ & $\begin{array}{l}\text { Google Drive / } \\
\text { download onto } \\
\text { Dropbox }<> \\
\text { hard drives }\end{array}$ & Yes & No & Internal & $\begin{array}{l}\text { Yes - onto } \\
\text { hard } \\
\text { drives }\end{array}$ & Not currently \\
\hline 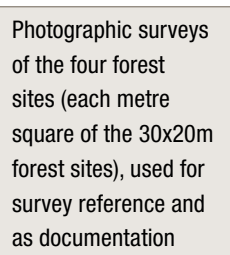 & .tiff / jpeg & $\begin{array}{l}30 \\
\text { Gb }\end{array}$ & $\begin{array}{l}\text { Canon 6D } \\
\text { DSLR camera } \\
\text { / Photoshop }\end{array}$ & $\begin{array}{l}\text { Dropbox <> } \\
\text { hard drives }\end{array}$ & Yes & $\begin{array}{l}\text { Yes as } \\
\text { collage } \\
\text { images of } \\
\text { each site }\end{array}$ & $\begin{array}{l}\text { Internal } \\
\text { mainly (but } \\
\text { some on } \\
\text { website / } \\
\text { used for } \\
\text { press) }\end{array}$ & $\begin{array}{l}\text { Yes - onto } \\
\text { hard } \\
\text { drives }\end{array}$ & Not currently \\
\hline $\begin{array}{l}\text { Illustrations of } \\
\text { selectede organisms } \\
\text { by the artist Katie } \\
\text { Scott. This material } \\
\text { was used in visual } \\
\text { explanations for } \\
\text { the audience and in } \\
\text { various marketing } \\
\text { materials. }\end{array}$ & .tiff / eps & $400 \mathrm{Mb}$ & $\begin{array}{l}\text { Adobe } \\
\text { lllustrator/ } \\
\text { Hand drawn }\end{array}$ & $\begin{array}{l}\text { Dropbox <>> } \\
\text { hard drives }\end{array}$ & Yes & $\begin{array}{l}\text { Yes } \\
\\
\text { print } \\
\text { versions } \\
\text { etc } \\
\text { available }\end{array}$ & $\begin{array}{l}\text { Internal } \\
\text { mainly (but } \\
\text { some on } \\
\text { website / } \\
\text { used for } \\
\text { press) }\end{array}$ & $\begin{array}{l}\text { Yes - onto } \\
\text { hard } \\
\text { drives }\end{array}$ & Not currently \\
\hline $\begin{array}{l}\text { References field } \\
\text { recordings of the four } \\
\text { forest sites. These } \\
\text { recordins were used } \\
\text { to identify bird song } \\
\text { and animal calls, } \\
\text { and as a aid in } \\
\text { balancing the sound } \\
\text { mix of the piece. }\end{array}$ & wav & $\begin{array}{l}30 \\
\text { Gb }\end{array}$ & $\begin{array}{l}\text { Zoom H6, } \\
\text { Tascam P2, } \\
\text { DPA4060 } \\
\text { Microphones } \\
\text { / Pro Tools }\end{array}$ & $\begin{array}{l}\text { Dropbox }<>> \\
\text { hard drives }\end{array}$ & Yes & $\begin{array}{l}\text { Yes (editited } \\
\text { selection } \\
\text { available } \\
\text { for use) }\end{array}$ & Internal only & $\begin{array}{l}\text { Yes - onto } \\
\text { hard drives }\end{array}$ & Not currently \\
\hline $\begin{array}{l}\text { Site and development } \\
\text { documentation, across } \\
\text { the four sites. This } \\
\text { material was used } \\
\text { as a documentation } \\
\text { of the process of the } \\
\text { creation of the piece } \\
\text { for future papers } \\
\text { and presentations } \\
\text { about the piece. }\end{array}$ & $\begin{array}{l}\text { HD film in } \\
\text {.mov format } \\
\text { and HR } \\
\text { photography } \\
\text { in .tiff format }\end{array}$ & $\begin{array}{l}10 \\
\text { Gb }\end{array}$ & $\begin{array}{l}\text { Canon 6D } \\
\text { DSLR camera } \\
\text { / Photoshop }\end{array}$ & $\begin{array}{l}\text { Dropbox }<> \\
\text { hard drives }\end{array}$ & Yes & $\begin{array}{l}\text { Yes (edited } \\
\text { selection } \\
\text { avallable } \\
\text { for use) }\end{array}$ & $\begin{array}{l}\text { Internal mainly } \\
\text { (but some } \\
\text { on website } \\
\text { / used for } \\
\text { documentation } \\
\text { film) }\end{array}$ & $\begin{array}{l}\text { Yes - onto } \\
\text { hard drives }\end{array}$ & Not currently \\
\hline $\begin{array}{l}\text { Recordings of the } \\
\text { scored musical } \\
\text { framentst that make } \\
\text { up the piece, derived } \\
\text { from sessions with } \\
\text { over } 50 \text { musicians in } \\
\text { studios across the UK. }\end{array}$ & $\begin{array}{l}\text { wav / Pro } \\
\text { Tools sessions } \\
\text { (.pts)/ / } \\
\text { Liveleton } \\
\text { Live sessions } \\
\text { (.als) }\end{array}$ & $\begin{array}{l}150 \\
\text { Gb }\end{array}$ & $\begin{array}{l}\text { Numerous } \\
\text { microphones. } \\
\text { Recorded into } \\
\text { Pro Tools (.pts) } \\
\text { as .wav files and } \\
\text { then worked } \\
\text { in Ableton } \\
\text { Live (.als) }\end{array}$ & $\begin{array}{l}\text { Dropbox }<>> \\
\text { hard drives }\end{array}$ & Yes & $\begin{array}{l}\text { Yes (but } \\
\text { only for } \\
\text { use within } \\
\text { the master } \\
\text { score for } \\
\text { the piece) }\end{array}$ & Internal only & $\begin{array}{l}\text { Yes - onto } \\
\text { hard drives }\end{array}$ & Not currently \\
\hline $\begin{array}{l}30 \text { software } \\
\text { simulations of the } \\
\text { forest sites created } \\
\text { from the survey datata }\end{array}$ & $\begin{array}{l}\text { software } \\
\text { package - } \\
\text { python, C++, } \\
\text { MaxForlive }\end{array}$ & 500Mb & Custom software & $\begin{array}{l}\text { Dropbox }<> \\
\text { hard drives }\end{array}$ & Yes & I & Internal only & $\begin{array}{l}\text { Yes - onto } \\
\text { hard drives }\end{array}$ & Not currently \\
\hline
\end{tabular}

Working in remote forests across England was a challenge for capturing and storing data, as Internet/ network access was extremely limited. As a result, the data was regularly backed up and duplicated onto hard drive storage, before then being synchronized to cloud storage at a later point. For immediate 'transfer' purposes all data gathered was placed into Dropbox (for sharing with partners including press organisations, Sound and Music and Forestry Commission England) and then transferred to external hard drive storage (copies were synced and held both at the Jones/Bulley studio and in personal artist studios offsite). Dropbox was used for its ease of use, stability and simple sharing interface.

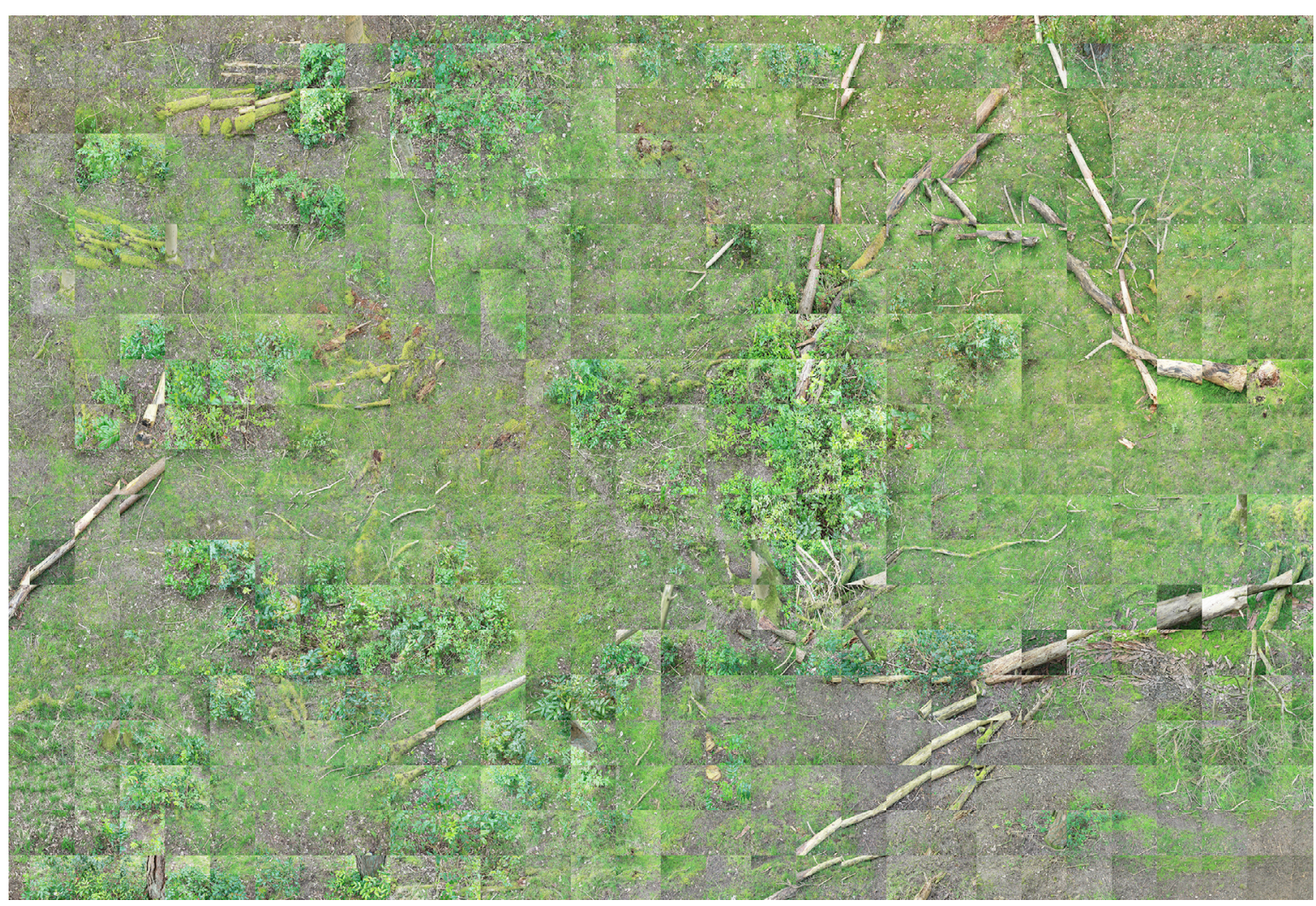

Figure 10.2 Thetford Forest Photographic Survey, 2014 (Photograph: James Bulley)

Figure 10.1 Table of datasets 


\subsection{ANCILLARY DATA}

During the live period as the installation toured, there were a number of additional datasets that were captured by the artists and the production team as part of the project.

A table of datasets captured during the project is included in Figure 10.3

\begin{tabular}{|c|c|c|c|c|c|c|c|c|c|}
\hline $\begin{array}{l}\text { Type of } \\
\text { dataset }\end{array}$ & Format & Size & $\begin{array}{l}\text { Capture } \\
\text { Tools/ } \\
\text { Software }\end{array}$ & $\begin{array}{l}\text { Backup/ } \\
\text { Storage }\end{array}$ & Raw & Prepared & $\begin{array}{l}\text { Shared } \\
\text { with }\end{array}$ & Archived & Accessible \\
\hline $\begin{array}{l}\text { Written } \\
\text { testimonials } \\
\text { (blogososts, } \\
\text { handwritten } \\
\text { feedback } \\
\text { forms } \\
\text { regarding } \\
\text { audience } \\
\text { experience) }\end{array}$ & doc / paper & 5Mb & $\begin{array}{l}\text { Journal articles } \\
\text { / written } \\
\text { testimonies } \\
\text { on paper }\end{array}$ & $\begin{array}{l}\text { Dropbox }<> \\
\text { Hard disks I } \\
\text { physical backup } \\
\text { in studio boxes }\end{array}$ & Yes & Yes & $\begin{array}{l}\text { Some } \\
\text { public, } \\
\text { some } \\
\text { internal } \\
\text { only }\end{array}$ & $\begin{array}{l}\text { Yes - onto } \\
\text { hard } \\
\text { drives }\end{array}$ & Not currently \\
\hline $\begin{array}{l}\text { Press articles } \\
\text { and coverage } \\
\text { (BBC news, } \\
\text { Nature Journal } \\
\text { vidide feature, } \\
\text { Guardian, } \\
\text { feature etc) }\end{array}$ & pdf captures & $3 \mathrm{~Gb}$ & $\begin{array}{l}\text { Paparazzi } \\
\text {.pdf screen } \\
\text { capture } \\
\text { software / } \\
\text { print to pdf } \\
\text { function } \\
\text { on Google } \\
\text { Chrome. } \\
\text { Videos as } \\
\text { downloads } \\
\text { (or sent in } \\
\text { links from } \\
\text { producers) }\end{array}$ & $\begin{array}{l}\text { Dropbox<>> } \\
\text { Hard disks }\end{array}$ & Yes & Yes & $\begin{array}{l}\text { Internal } \\
\text { only }\end{array}$ & $\begin{array}{l}\text { Ves - onto } \\
\text { hard } \\
\text { drives }\end{array}$ & Not currently \\
\hline $\begin{array}{l}\text { Video } \\
\text { documentation } \\
\text { of the sites } \\
\text { (both with } \\
\text { and without } \\
\text { aduience } \\
\text { presence) }\end{array}$ & .mov HR files & 150Gb & $\begin{array}{l}\text { Canon 6D } \\
\text { DSLR camera }\end{array}$ & $\begin{array}{l}\text { Dropbox <> } \\
\text { Hard disks }\end{array}$ & Yes & № & \begin{tabular}{l|} 
Internal \\
only \\
(possibibe \\
future use)
\end{tabular} & $\begin{array}{l}\text { Yes - onto } \\
\text { hard } \\
\text { drives }\end{array}$ & Not currently \\
\hline $\begin{array}{l}\text { Audio } \\
\text { documentation } \\
\text { of the piece } \\
\text { live at each } \\
\text { site }\end{array}$ & wav files & 50Gb & $\begin{array}{l}\text { recorded on } \\
\text { ZoomH6 with } \\
\text { DPA4060 } \\
\text { microphones } \\
\text { (and various } \\
\text { others) }\end{array}$ & $\begin{array}{l}\text { Dropbox <> } \\
\text { Hard disks }\end{array}$ & Yes & $\begin{array}{l}\text { Yes (edited highlights } \\
\text { selected and used on } \\
\text { video documentation) }\end{array}$ & \begin{tabular}{|l|} 
Internal \\
only \\
(possible \\
uture use)
\end{tabular} & $\begin{array}{l}\text { Yes - onto } \\
\text { hard } \\
\text { drives }\end{array}$ & Not currently \\
\hline $\begin{array}{l}\text { Photographic } \\
\text { documentation } \\
\text { of the piece } \\
\text { and the } \\
\text { forest sites }\end{array}$ & $\begin{array}{l}\text {.tiff files / } \\
\text {.jpeg files }\end{array}$ & 10Gb & $\begin{array}{l}\text { Canon 6D } \\
\text { DSLR camera }\end{array}$ & $\begin{array}{l}\text { Dropbox }<> \\
\text { Hard disks }\end{array}$ & Yes & $\begin{array}{l}\text { Yes (edited highlights } \\
\text { package created } \\
\text { for press use and } \\
\text { website use) }\end{array}$ & \begin{tabular}{l|} 
Internal \\
only \\
(possibibe \\
future use)
\end{tabular} & $\begin{array}{l}\text { Yes - onto } \\
\text { hard } \\
\text { drives }\end{array}$ & Not currently \\
\hline $\begin{array}{l}\text { Captures of the } \\
\text { weather data }\end{array}$ & $\begin{array}{l}. c 5 v \text { files / } \\
\text { xls files }\end{array}$ & 20Mb & $\begin{array}{l}\text { Weather } \\
\text { station } \\
\text { through } \\
\text { custom } \\
\text { software }\end{array}$ & $\begin{array}{l}\text { Dropbox <> } \\
\text { Hard disks }\end{array}$ & Yes & No & $\begin{array}{l}\text { Internal } \\
\text { only }\end{array}$ & $\begin{array}{l}\text { Yes - } \\
\text { onto } \\
\text { hard } \\
\text { drives }\end{array}$ & Not currently \\
\hline
\end{tabular}

Figure 10.3 Table of ancillary datasets

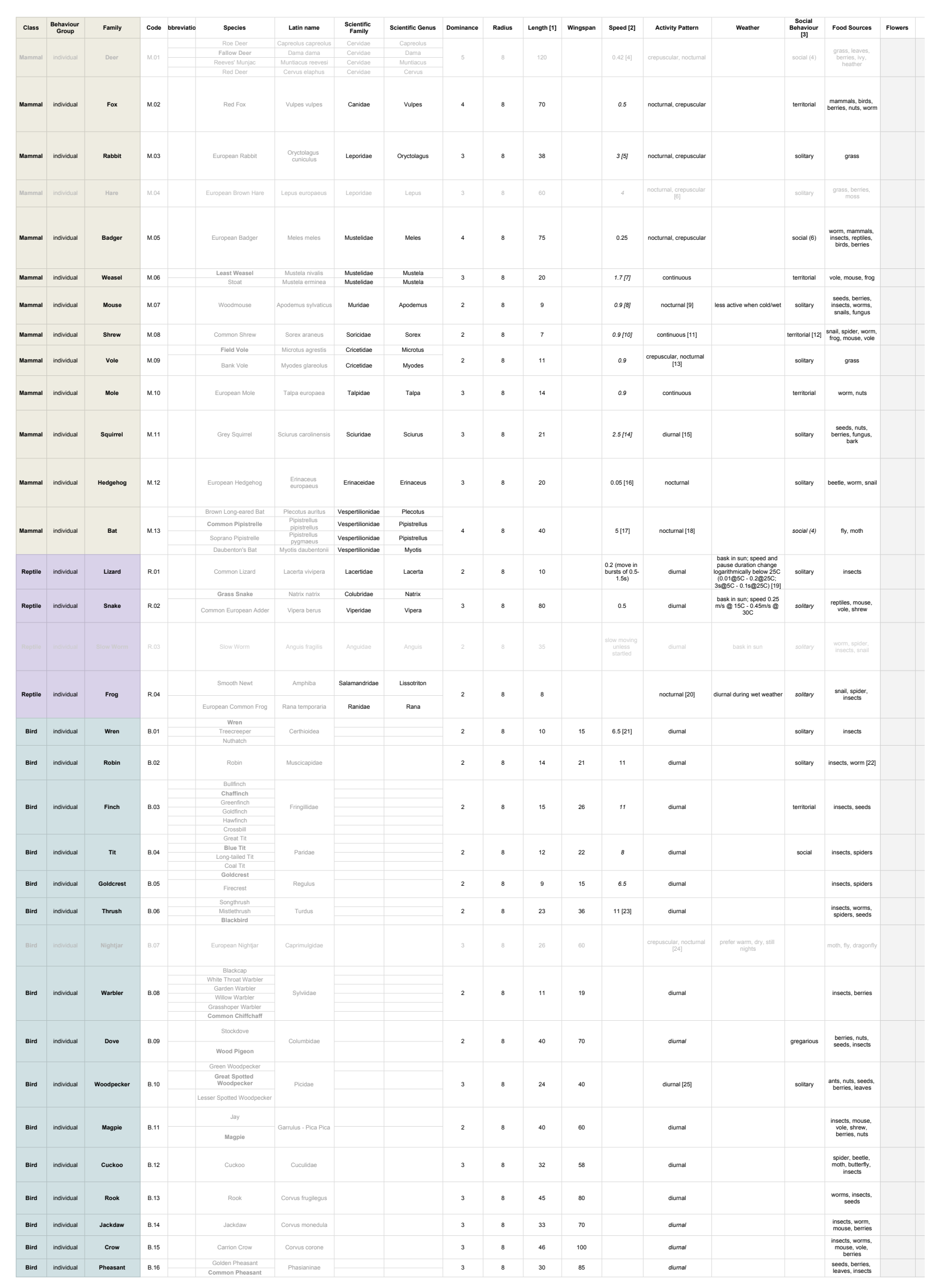

10.4 Excerpt from Living Symphonies full organism survey, 2014 


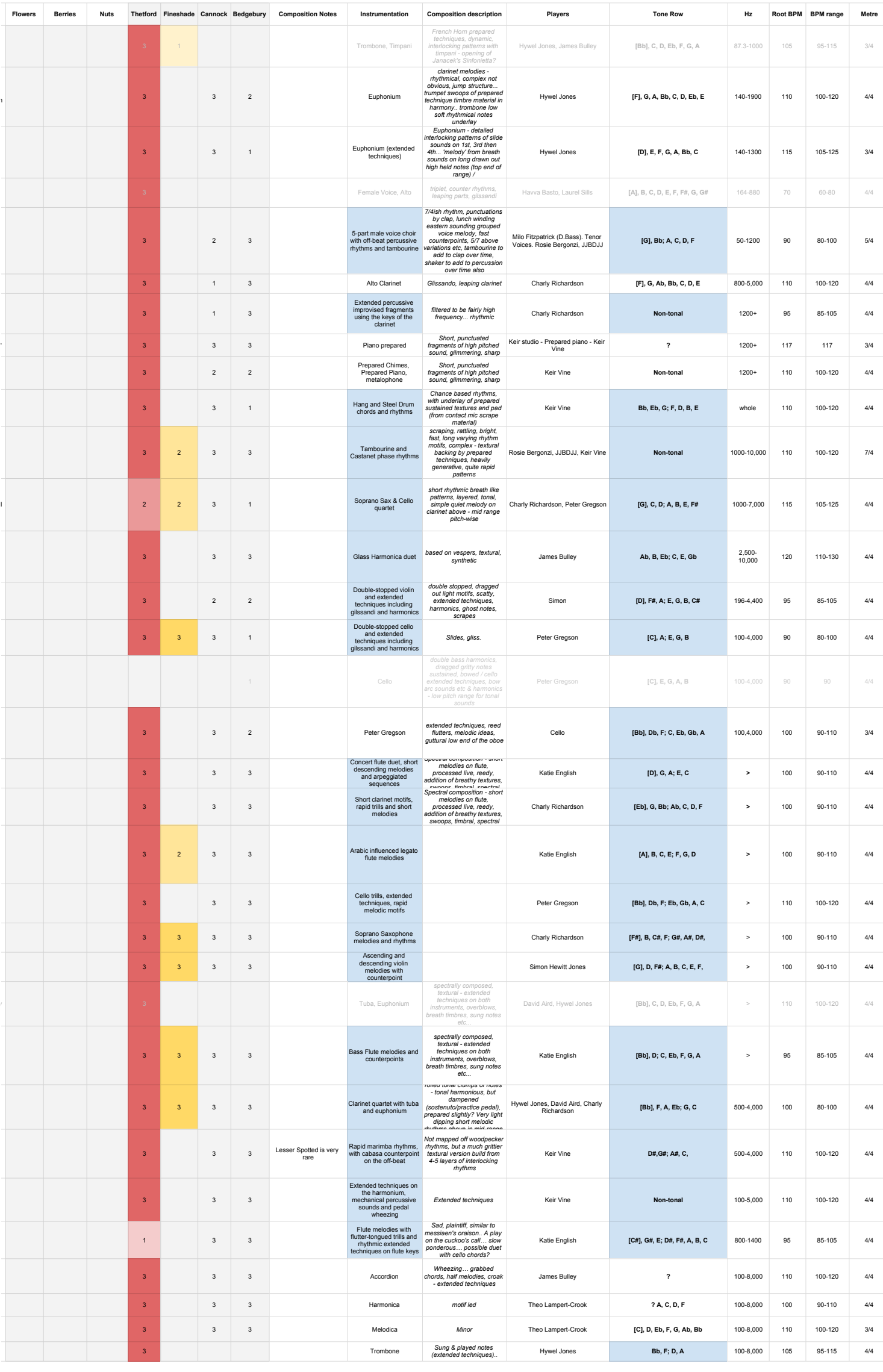

10.4 Excerpt from Living Symphonies full organism survey, 2014
[This taxonomy details every living organism (in genus groups) and its related music across all four sites of the 2014 tour of Living Symphonies]

\subsection{SHARING OF DATA}

The sharing of the data that underpins Living Symphonies has been a complex and near impossible task. Whilst the partner organisations did create a toolkit that explored the touring of the piece (which was a prerequisite of the Arts Council funding that the piece obtained), it has not been possible to make available the vast majority of the above data in any coherent way. It is clear that most of this data would be very useful to many other researchers and artists (as proven by the interest of numerous academics, musicians and ecologists). However, in order to achieve this there would need to be funding allocated to provide the time for the adequate preparation of the datasets with related material to explain and contextualise them. Some of the photography and video has been used to make short reference films and to provide visual contex to document the occurrence of the work, but it has not been possible for the artists to make the following datasets available due to a lack of funding, time constraints surrounding its curation and contextualization, i.e. ranges of data and editing of documentation material, and issues in hosting such large quantities of material. Bracketed after these datasets are the avenues that the artists would hope and plan to make the material available through if possible:

- forest survey data (Goldsmiths Data Repository - data.gold.ac.uk, livingsymphonies.com)

- field recordings (Goldsmiths Data Repository - data.gold.ac.uk, freesound.org)

- weather datasets (Goldsmiths Data Repository - data.gold.ac.uk, livingsymphonies.com)

- photography (Goldsmiths Data Repository - data.gold.ac.uk, flickr.com)

- film (Goldsmiths Data Repository - data.gold.ac.uk, livingsymphonies.com)

- custom unique software (Goldsmiths Data Repository - data.gold.ac.uk, github)

- sound score materials (Goldsmiths Data Repository - data.gold.ac.uk, freesound.org)

\subsection{CONCLUSION}

Whilst much discussion has occurred in recent years surrounding research data management in the context of science-centred and text-based research outputs, very little of this has involved confronting the problems facing artist-researchers working outside these areas. As a result of fundamental differences in the commissioning and funding structures for art projects, there is insufficient funding and understanding on the part of the artists and institutions involved as to how or even why it is worth making this data available. Living Symphonies provides a case study that highlights a large and wide-ranging array of datasets that would undoubtedly be useful for researchers across numerous disciplines. In this instance the artists/ researchers are comfortable with the vast majority of the data being made available under one of the more openly accessible of Creative Commons licenses - in this instance this would not affect any further income for the artists as the pieces in themselves are unrepeatable due to their site-specific nature. The artists believe this would be the right thing to do, given the publicly funded nature of the project. This data will remain unavailable unless there is adequate funding and planning from the outset for projects such as these.

research and innovation programme under grant agreement No 654139. 